\title{
The Extruded Granule Formulation of Selective Rice Herbicide Cyhalofop Butyl
}

\author{
Naohiko Kondo*, Tetsuo Matsumoto*, Kuni Matsuya*, Hisao Katahashi* \\ and Yasufumi Imai*
}

\begin{abstract}
Cyhalofop butyl, $\left[\mathrm{R}-(+)-\mathrm{n}^{-}\right.$ butyl - 2 - (4 - (2 - fluoro - 4 - cyanophenoxy) phenoxy) propionate] is a selective rice graminicide which can control up to the 5-6 leaf stage of Echinochloa crus-galli by foliar application. The development of granule formulations for rice herbicides is important to strengthen agricultural practices in Japan. One granule system of cyhalofop butyl employs $\mathrm{KCl}$ core granules and di-tridecyl phthalate to maximize its bioefficacy. As described in a previous report, this system can enhance plant uptake of the graminicide when a high concentration of cyhalofop butyl plus di-tridecyl phthalate comes into direct contact with a plant. The system does, however, limit the flexibility of one shot granule formulations depending on the $\mathrm{KCl}$ core granule compatibility with the partner with which it is combined. Therefore, an extruded granule of cyhalofop butyl is preferable to a $\mathrm{KCl}$ granule of cyhalofop butyl to broaden the potential/possible partners for a one shot granule. Several core granule systems and solvent systems were evaluated to develop an efficacious extruded granule of cyhalofop butyl. Among them, the employment of maleic acid polymer type surfactant for the extruded core granule system and di-tridecyl phthalate plus isoparaffin as solvent system showed the best bioefficacy to control the 3

\footnotetext{
* Dow AgroSciences Division, Dow Chemical Japan Limited

(Accepted June 12, 1996)
}

leaf stage of Echinochloa crus-galli than did the $\mathrm{KCl}$ granule of cyhalofop butyl. Granules extruded by this system also showed a high release rate of the graminicide in the upper layer of the water.

Key words; Cyhalofop butyl, Echinochloa crus-galli, granule, maleic acid polymer type surfactant, isoparaffin

\section{Introduction}

Cyhalofop butyl, known as XDE-537 or $\mathrm{DEH}-112$, is a new post-emergence aryloxyphenoxy propionate graminicide discovered by Dow AgroSciences which controls a broad spectrum of grass weeds, including genera of Echinochloa, Brachiaria, Cynodon, Digitaria, Eleusine, Leptochloa, Panicum, Setaria and Sorghum. Cyhalofop butyl is highly selective to both Japonica and Indica rice varieties as well as to all broadleaf rotational crop species $^{6}$. It has a broad window of application (1-6 leaf Echinochloa crus-galli) and also the ability to mix with a number of other herbicides ${ }^{5}$. Since the 1960 s the major formulation type of herbicides used in Japan for paddy fields has been granule formulations ${ }^{4}$. Therefore, a granule formulation of cyhalofop butyl is essential for the Japanese herbicide market ${ }^{4}$. One granule system which employs KClcore granules and di-tridecyl phthalate maximizes the bioefficacy of cyhalofop butyl ${ }^{2,3)}$. However, this system limits formulation flexibility for one shot 
granule formulations, and depends on $\mathrm{KCl}$ core granule compatibility with its combination partners. Therefore, extruded granules of cyhalofop butyl are preferable to the $\mathrm{KCl}$ granules $^{7)}$, although the conventional type of extruded granules have shown poor bioefficacy. Formulation studies were conducted to find an efficacious extruded granule of cyhalofop butyl which would show equal or at least nearly as good bioefficacy in controlling 3 leaf stage of E. crus-galli than the $\mathrm{KCl}$ granule system. This report covers evaluations of various extruded granule formulations tested for this purpose.

\section{Materials and Methods}

Physical and chemical properties of the active ingredient : Physical and chemical properties of cyhalofop butyl are shown in Fig. 1.

Formulation

Extruded granule formulations for core

Code name : XDE-537, DEH-112

$\begin{array}{ll}\begin{array}{l}\text { Common name : } \\ \text { Chemical name : }\end{array} & \begin{array}{l}\text { cyhalofop butyl } \\ \text { [R-(+)-n-butyl-2-(4-(2-fluoro-4- } \\ \text { cyanophenoxy)phenoxy)-propionate] }\end{array} \\ \text { Empirical formula : } & \mathrm{C}_{20 \mathrm{H} 20 \mathrm{FNO} 4} \\ \text { Molecular weight : } & \\ \text { Structural formula : }\end{array}$

Appearance : $\quad$ odorless, white, crystalline solid

Melting point : $\quad 50^{\circ} \mathrm{C}$

Solubility (at $20^{\circ} \mathrm{C}$ ) : Water: $\quad 0.7 \mathrm{ppm}(\mathrm{pH} \mathrm{7.0)}$

Xylene: 47.3 (wt\% a.i.)

Acetone: 60.7 (wt\% a.i.)

Octanol-water partition coefficient $(\log \mathrm{P}): 3.31$

Vapor pressure: $\quad 8.8 \times 10^{-9} \mathrm{mmHg}$ at $20^{\circ} \mathrm{C}$

Fig. 1. Physical and chemical properties of cyhalofop butyl granule system optimization : Test formulations containing $0.6 \%$ of cyhalofop butyl were prepared to evaluate the core granule system. (Fig. 2)

Extruded granule formulations for solvent system optimization : Test formulations contained $0.6 \%$ of cyhalofop butyl. (Fig. 3)

Release rate test for cyhalofop butyl : One -tenth of a gram of each granule was placed into a specially made "funnel flask", to which $20 \mathrm{ml}$ of water was added. After standing for 24 hours, the stopcock was closed and the upper layer of the water was collected by washing with acetone and filled to $50 \mathrm{ml}$. Cyhalofop butyl was then analyzed by a high performance liquid chromatograph (HPLC). The HPLC used was a HP1090LC (Hewlett Packard) equipped with a UV detector (250 $\mathrm{nm}$, Shimadzu model SPD-6A). The column was an Apex-ODS $(250 \times 4.6 \mathrm{~mm})$. Mobile phase consisted of $50 \%$ acetonitrile and $50 \%$

(1) Extruded Core Granule
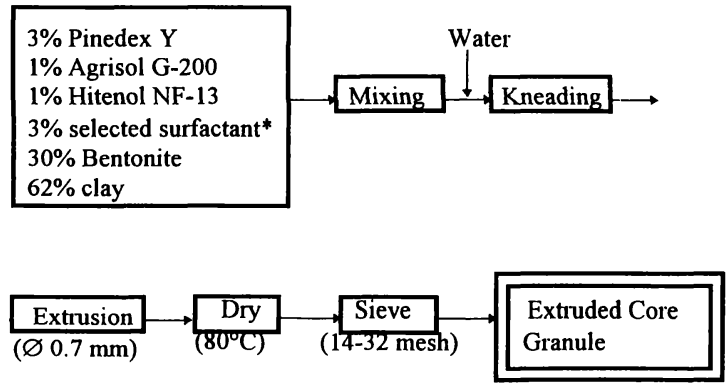

(2) Test Formulations

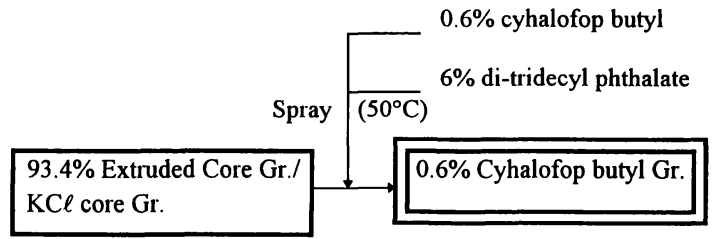

*Selected surfactant : Meleic acid polymer type, Acetylene glycol type, Naphthalene sulphonic acid sodium salt

Fig. 2. Formulation process on test formulations for core granule system optimization 


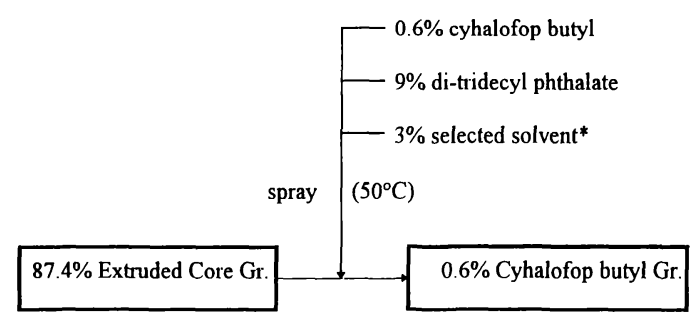

*Selected solvent : isoparaffin, ditolyl methyl methane, solvesso 150 , solvesso 200 , cyclo paraffin, paraffinic petroleum hydrocarbon

Fig. 3. Formulation process on test formulations for solvent system optimization

water containing $0.1 \%$ of acetic acid, and the flow rate was $1 \mathrm{ml} / \mathrm{min}$. The procedure of the release rate test is shown in Fig. 4.

Herbicidal efficacy trials

1) Greenhouse trial 1: For core granule system optimization

The bioefficacy of extruded granule formulations of $0.6 \%$ cyhalofop butyl was evaluated in comparison with that of $\mathrm{KCl}$ granules of $0.6 \%$ cyhalofop butyl under a greenhouse condition at the Gotemba laboratory of Dow AgroSciences. A Wagner's pot $1 / 5000$ in size was used for the trial and the water level was maintained at $3 \mathrm{~cm}$. E. crus-galli at the 2.0 2.5 leaf stage was treated with cyhalofop butyl granule formulations at $180 \mathrm{~g}$ ai/ha. Visual assessment of herbicide activity was made 28 days after the application with 3 replications $(0 \%$ : no effect-100; : complete kill).

2) Greenhouse trial $2:$ For solvent system optimization

The bioefficacy of $0.6 \%$ extruded granule formulations of cyhalofop butyl was evaluated to select the best solvent system under a greenhouse condition at the Fukuoka field station of Dow AgroSciences. A 1/5000 Wagner's pot was used and the water level was maintained at $3 \mathrm{~cm}$. E. crus-galli at the

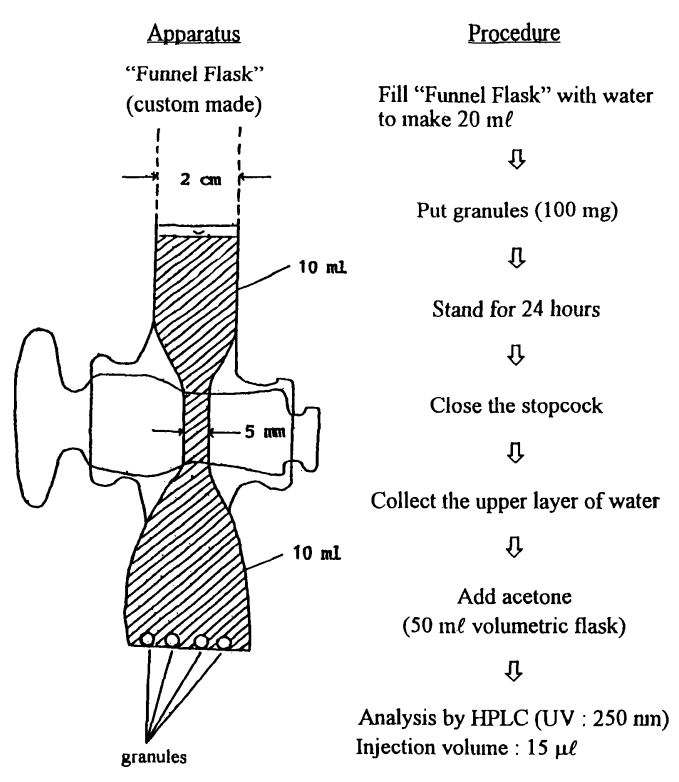

Fig. 4. Method for release rate test

3 leaf stage was treated with the formulations, and visual assessment of herbicide activity was made 27 days after the application with 3 replications ( $0 \%$ : no effect $-100 \%$ complete kill)

\section{Results and Discussion}

\section{Herbicidal efficacy trials}

1) Greenhouse trial 1: Cyhalofop butyl granules containing $3 \%$ maleic acid polymer type surfactant in the core granule system showed the highest efficacy in controlling the 2.0-2.5 leaf stage of E. crus-galli and was superior to the reference formulation, $\mathrm{KCl}$ granules of cyhalofop butyl under a greenhouse condition (Table 1).

Based on these results, the core granule system containing 3\% maleic acid polymer type surfactant was determined to be the best system for cyhalofop butyl extruded granules.

2) Greenhouse trial 2 : Cyhalofop butyl granules containing 3\% isoparaffin, solvesso 200 and cycloparaffin as solvent system 
Table 1. Core granule system optimization on cyhalofop-butyl granule formulations-efficacy against $E$. crusgalli

\begin{tabular}{|c|c|c|c|}
\hline Formulation* & Surfactant for core granule & $\begin{array}{c}\text { Rate } \\
\text { g a.i./ha }\end{array}$ & $\begin{array}{l}\% \text { Control of } \\
\text { E. crus-galli } \\
\text { at } 28 \mathrm{DAA}^{* *}\end{array}$ \\
\hline $\begin{array}{l}\text { Cyhalofop butyl } \\
0.6 \% \mathrm{Gr}\end{array}$ & Maleic acid polymer type & 180 & 90 \\
\hline $\begin{array}{l}\text { Cyhalofop butyl } \\
0.6 \% \mathrm{Gr}\end{array}$ & Acetylene glycol type & 180 & 47 \\
\hline $\begin{array}{l}\text { Cyhalofop butyl } \\
0.6 \% \mathrm{Gr}\end{array}$ & $\begin{array}{l}\text { Naphthalene sulphonic } \\
\text { acid sodium salt }\end{array}$ & 180 & 73 \\
\hline $\begin{array}{l}\text { Cyhalofop butyl } \\
0.6 \% \mathrm{KCl} \mathrm{Gr} \\
\text { (reference) }\end{array}$ & - & 180 & 73 \\
\hline Leaf stage at application & & \multicolumn{2}{|c|}{$2.0-2.5$ leaf } \\
\hline
\end{tabular}

Formulation* : $6 \%$ Di-tridecyl phthalate as oil system

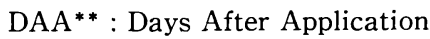

Table 2. Solvent system optimization on cyhalofop butyl granule formulations-efficacy against $E$. crus-galli

\begin{tabular}{|c|c|c|c|}
\hline Formulation & Solvent system & $\begin{array}{c}\text { Rate } \\
\text { g a.i./ha }\end{array}$ & $\begin{array}{c}\% \text { control of } \\
E \text {. crus-galli } \\
\text { at } 27 \mathrm{DAA}^{*}\end{array}$ \\
\hline Cyhalofop butyl & $9 \%$ Di-tridecyl phthalate & 180 & 95 \\
\hline \multirow{2}{*}{$0.6 \% \mathrm{Gr}$} & + & 120 & 86 \\
\hline & $3 \%$ Isoparaffin & 60 & 72 \\
\hline Cyhalofop butyl & $9 \%$ Di-tridecyl phthalate & 180 & 85 \\
\hline \multirow[t]{2}{*}{$0.6 \% \mathrm{Gr}$} & + & 120 & 75 \\
\hline & $3 \%$ Ditolyl methyl methane & 60 & 65 \\
\hline Cyhalofop butyl & $9 \%$ Di-tridecyl phthalate & 180 & 85 \\
\hline \multirow[t]{2}{*}{$0.6 \% \mathrm{Gr}$} & + & 120 & 67 \\
\hline & $3 \%$ Solvesso 150 & 60 & 60 \\
\hline Cyhalofop butyl & $9 \%$ Di-tridecyl phthalate & 180 & 96 \\
\hline \multirow[t]{2}{*}{$0.6 \% \mathrm{Gr}$} & + & 120 & 87 \\
\hline & $3 \%$ Solvesso 200 & 60 & 68 \\
\hline Cyhalofop butyl & $9 \%$ Di-tridecyl phthalate & 180 & 97 \\
\hline \multirow[t]{2}{*}{$0.6 \% \mathrm{Gr}$} & + & 120 & 77 \\
\hline & $3 \%$ Cycloparaffin & 60 & 63 \\
\hline Cyhalofop butyl & 9\% Di-tridecyl phthalate & 180 & 88 \\
\hline \multirow[t]{2}{*}{$0.6 \% \mathrm{Gr}$} & + & 120 & 78 \\
\hline & $3 \%$ Paraffinic petroleum hydrocarbons & 60 & 57 \\
\hline Cyhalofop butyl & $9 \%$ Di-tridecyl phthalate & 180 & 99 \\
\hline \multirow[t]{2}{*}{$0.6 \% \mathrm{Gr}$} & $(\mathrm{KCl}$ core $\mathrm{Gr})$. & 120 & 99 \\
\hline & & 60 & 93 \\
\hline Leaf stage at application & & \multicolumn{2}{|c|}{3.0 leaf } \\
\hline
\end{tabular}

DAA* : Days After Application 
showed stable efficacy in controlling the 3.0 leaf stage of $E$. crus-galli from $180 \mathrm{~g}$ ai/ha to $60 \mathrm{~g}$ ai/ha application among the formulations evaluated under a greenhouse condition in comparison with $0.6 \% \mathrm{KCl}$ granules of cyhalofop butyl (Table 2).

This suggested there would be a clear enhancement of plant uptake of the graminicide by employing the appropriate surfactant and solvent in the granule composition. More finely tuned studies should permit reduction in the amount of cyhalofop butyl used in the extruded granule, and the solvent system containing 3\% isoparaffin was selected for further studies.

3) Release rate of $0.6 \%$ cyhalofop butyl extruded granule formulations for solvent system optimization

The release rate of each selected formulation before and after storage at $50^{\circ} \mathrm{C} \times 2$ weeks was analyzed to identify the one with the most stable release rate performance even after storage at $50^{\circ} \mathrm{C}$.

The results showed there was no close correlation between bioefficacy and release rate performance. Three formulations containing $3 \%$ each of isoparaffin, or ditolyl methyl methane or cycloparaffin showed a relatively high and stable release rate before and after the storage test at $50^{\circ} \mathrm{C} \times 2$ weeks from a stability point of view (Table 3 ).

4) Release rate pattern of $0.6 \%$ cyhalofop butyl extruded granule formulations for 3, 6 and 24 hours

The release rate of the 3 formulations containing $3 \%$ each of isoparaffin, ditolyl methyl methane, or cycloparaffin was analyzed after standing for 3,6 and 24 hours to show the release rate pattern of each extruded granule. The granules containing 3\% isoparaffin showed a higher release rate than those containing $3 \%$ cycloparaffin or $3 \%$ ditolyl methane for the 3-24 hour period and a rate almost equal to $\mathrm{KCl} \mathrm{Gr}$. at 24 hours (Fig. 5.)

In conclusion, by employing maleic acid polymer type surfactant for the extruded core granule system and isoparaffin as solvent system in tested granule formulations better bioefficacy was shown in controlling the 3 leaf stage of $E$. crusgalli. This granule system also showed relatively quick and stable release rate performance before and after $50^{\circ} \mathrm{C} \times 2$ weeks storage.

The composition of the best extruded granule would be applicable to a one shot granule

Table 3. Optimization of solvent system*

\begin{tabular}{|c|c|c|c|}
\hline \multirow[t]{2}{*}{ Formulation } & \multirow[t]{2}{*}{ Solvent } & \multicolumn{2}{|c|}{$\begin{array}{c}\text { Release rate }(\%) \\
\text { at } 24 \mathrm{hrs} \text { after application }\end{array}$} \\
\hline & & Initial & $50^{\circ} \mathrm{C} \times 2$-week \\
\hline Cyhalofop butyl $0.6 \% \mathrm{Gr}$ & Isoparaffin & 96 & 92 \\
\hline Cyhalofop butyl $0.6 \% \mathrm{Gr}$ & Ditolyl methyl methane & 90 & 89 \\
\hline Cyhalofop butyl $0.6 \% \mathrm{Gr}$ & Solvesso 150 & 95 & 88 \\
\hline Cyhalofop butyl $0.6 \% \mathrm{Gr}$ & Solvesso 200 & 62 & 63 \\
\hline Cyhalofop butyl $0.6 \% \mathrm{Gr}$ & Cycloparaffin & 92 & 90 \\
\hline Cyhalofop butyl $0.6 \% \mathrm{Gr}$ & $\begin{array}{l}\text { Paraffinic petroleum } \\
\text { hydrocarbons }\end{array}$ & 100 & 87 \\
\hline
\end{tabular}

*Solvent system : $9 \%$ Di-tridecyl phthalate $+3 \%$ solvent 


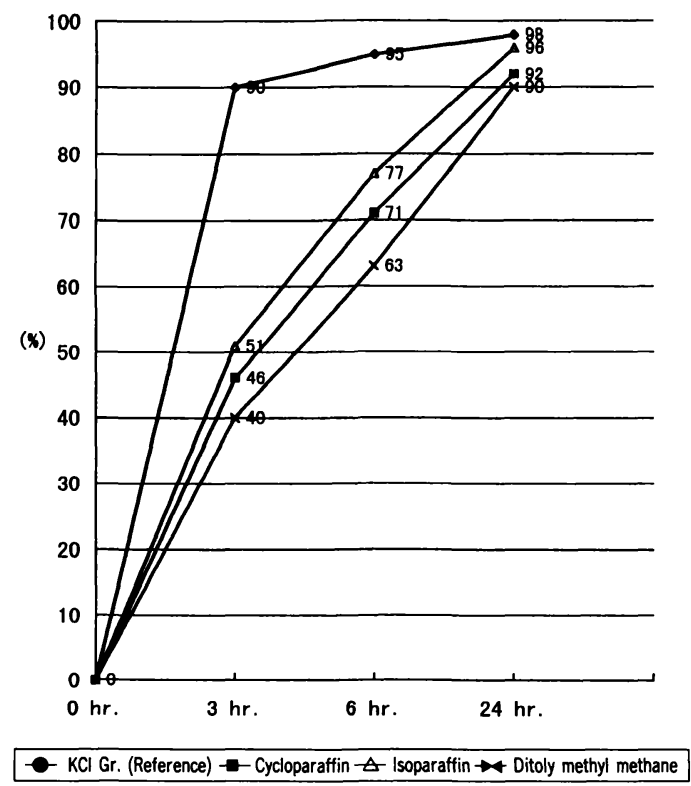

Fig. 5. Difference in release rate pattern among 3 solvent systems versus $\mathrm{KCl}$ granule

formulation of cyhalofop butyl due to there being better compatibility and more flexibility than with the $\mathrm{KCl}$ granule, although the latter is appropriate for a single granule of this graminicide because of its stable bioefficacy.

\section{Acknowledgments}

The authors gratefully acknowledge the contributions made to this study by Mr. Johji

Ohdake and Mr. Masahiro Atsumi.

\section{References}

1 ) Gotoh, K. 1985. Plasticizers. In "Plastic \& Rubber Additives Handbook" ed. by S. Kamihara and M. Imoto, Kagaku Kogyo sha, Tokyo, pp. 52 (in Japanese)

2 ) Kondo, N., T. Matsumoto, K. Matsuya, H. Katahashi and Y. Imai, 1995. Cyhalofop Butyl : Formulation Technology on Cyhalofop Butyl Granule. Proc. 15th Conf. APWWS, 591-594.

3 ) Kondo, N., T. Matsumoto, K. Matsuya, H. Katahashi and Y. Imai, 1996. The granule formulation of selective rice herbicide cyhalofop butyl. Weed Res., Japan vol. 41 (3), 205-210

4 ) Konnai, M. 1994. Application methods. In "Weed Control Handbook" ed. by T. Kusanagi, M. Konnai and H. Shibayama, Asakura Press, Tokyo pp. 95-102 (in Japanese)

5 ) Matsumoto, T., K. Matsuya, H. Katahashi, N. Kondo and Y. Imai, 1993. Cyhalofop Butyl : Grass Herbicide-Field Performance in Rice in Japan. Proc. 14th Conf. APWSS, 149-153.

6 ) Ray, P. G., R. G. Pews, J. Secor and A. Hamburg, 1993. Cyhalofop Butyl : A New Graminicide for Use in Rice. Proc. 14th Conf. APWSS, 41-45.

7 ) Sekiguchi, M., I. Takahashi, A. Masui and T. Kojima, 1991. Development of Floating Granule Formulation Technology. Proc. 16th Annual Conference of Pesticide Science Society of Japan, 29-30 (in Japanese).

\section{水稲用選択性除草剤シハロホップブチルの押し 出し粒剤化}

近藤直彦*・松本哲男*・松谷 邦*・ 片橋久男*・今井康史*

\section{摘 要}

シハロホップブチル, [R-(+)-n-butyl-2-(4-(2-

\footnotetext{
*ダウ・ケミカル日本株式会社ダウ・アグロサイエンス事 業部門
}

fluoro-4-cyanophenoxy) phenoxy) propionate]は ダウ・アグロサイエンスにより開発中の水稲用選択 性除草剤である (Fig. 1)。本剤は, 茎葉処理におい て 5-6 葉期までのイヌビエ等に卓効を示すものの, 現在の日本の稲作の現状を考えると, シハロホップ ブチルの粒剤の製剤開発が必須である。しかしなが ら,これまでシハロホップブチルの一般的な押し出 し粒剤では, 期待された十分な効果を発揮させるこ とは困難であった。そこで, 押し出し粒剤の粒基剤 の界面活性剤及びその粒基剤にシハロホップブチル を含浸させる際に使用する溶剤の組み合わせを変え ることにより, 生物効果の向上が図れることが判明 
した。これらの組み合わせからなる各種シハロホッ プブチル $0.6 \%$ 押し出し粒剤の生物効果を温室内にて 評価した。押し出し粒剤の粒基剤中に $3 \%$ のマレイ ン酸ポリマー系界面活性肪を添加することにより, シハロホップブチルのイヌビエに対する効果が増強 されることがわかった (Table 2)。また, 溶剤の組 み合わせの中では, $9 \%$ di-tridecyl phthalate に 3 \%のイソパラフィンを添加したものが最も安定した シハロホップブチルの生物効果を示し (Fig. 3, Table 2,3), また, シハロホップブチルの水面浮上率の改
善に貢献した。

これらの結果より, シハロホップブチル押し出し 粒剤の粒基剤及びシハロホップブチルの含浸用の溶 剤を工夫することにより, 期待されるシハロホップ ブチルの生物効果を引き出すのが可能であることが 判明した。

キーワード：シハロホップブチル,イヌビエ, 粒刋, マレイン酸ポリマー系界面活性剤, イソパラフィン 